\title{
The Effect of Stocking Density on the Growth of Ocellaris Clownfish (Amphiprion ocellaris Cuvier, 1830) With Recirculation
}

\author{
Atiek Pietoyo ${ }^{1}$, Kurniawan Wahyu Hidayat ${ }^{1 *}$, Siti Nurazizah ${ }^{1}$, Irvan Firmansyah Zainul \\ Arifin $^{1}$, DH Guntur Prabowo ${ }^{1}$, Fajar Tri Widianto ${ }^{1}$ and Irpan Mustakim ${ }^{1}$ \\ ${ }^{1}$ Aquaculture Study Program, Polytechnique of Marine and Fishery Pangandaran, Jl. Raya Babakan, \\ Pangandaran 46396, Indonesia
}

*Correspondence :
kurniawanwahyu6@gmail.com

Received : 2019-11-20

Accepted : 2020-07-06

Keywords :

Amphiprion ocellaris, Ocellaris clownfish, Stocking density,

Recirculation system

\begin{abstract}
The ornamental fish business is now an economic driver. The ocellaris clownfish (Amphiprion ocellaris Cuvier, 1830) is one of the leading commodities of marine ornamental fish that is in great demand, especially in foreign markets. One obstacle faced by farmers in determining the appropriate density for the ocellaris clownfish rearing stage. This study aimed to evaluate the effect of stocking density on production factors, which included survival rate, and growth rate of ocellaris clownfish. Three hundred fish were used as experimental fish with an average length of $23.00 \pm 2.36 \mathrm{~mm}$ and a weight of $0.27 \pm 0.02$ gather study was conducted using 4 treatment tanks with a volume of $120 \mathrm{~L}$ with densities of $0.17,0.37,0.67$, and 0.80 fish/L. Observations showed that the density of 0.37 fish per L (K2) gave the best results with a survival rate of $98.18 \%$. For the SGR parameter, the highest value was $1.14 \%$ per day in the K1 treatment. This indicated that the stocking density has a relationship with the factor of production in rearing ocellaris clownfish in the recirculation system.
\end{abstract}

\section{INTRODUCTION}

Every year, the demand for marine ornamental fish continues to grow. However, many of these fish are caught from the wild using unsustainable methods using tranquilizers and nets that can damage the coral reef (Moorhead and Zeng, 2010; Chambel et al., 2015a; Araujo et al., 2014). The type of fish that is often the target is the ocellaris clownfish from the Pomacentridae family, especially the Amphiprion genus (Johnston et al., 2003).

Amphiprion ocellaris Cuvier, 1830 is a tropical fish found in colonies and has a mutualistic symbiosis with anemones. This fish is commonly found in the waters of the Pacific Ocean, Indian Ocean, northwest Australia, South East Asia, and Japan and is the most popular ornamental fish (Dhaneesh et al., 2012). According to Sari et al. (2014), A. ocellaris, or often also called anemonefish (fish that live between anemones) have a brownish-yellow to the orange base with three white bands and a little black on the head, body, and base of the tail.

According to Dambo and Rana (1993), stocking density can have a direct effect on vital parameters such as the survival rate, growth, behavior, water quality, and feed consumption rate. In aquaculture, the stocking density can be defined as the concentration of fish maintained in the system at individual units per area or volume unit (Gomes et al., 2006; de Oliveira et al., 2012). Generally, an increased stocking density 
would have a direct effect on the increased stress in the fish which in the end would decrease growth due to a decreased feeding response (Sharm and Chakrabarti, 1998).

However, too low of a stocking density would also affect the efficiency of space and resources; therefore, determining the right stocking density would not only improve efficiency and maximize production and profit, but it is also related to rearing (Leatherland and Cho, 1985).

This study was aimed to contribute to the development of rearing methods for A. ocellaris that had been previously developed (Setiawati and Hutapea, 2011). This study also evaluated the effect of the stocking density on the growth, and survival of $A$. ocellaris.

\section{METHODOLOGY}

\section{Place and Time}

The present study was conducted in the Laboratory of Aquaculture, Pangandaran Marine and Fishery Polytechnique. This study was conducted from June to December 2019.

\section{Research Material}

The test materials included $300 \mathrm{~A}$. ocellaris with an average length of $23.00 \pm$ $2.36 \mathrm{~mm}$ and an average weight of $0.27 \pm$ $0.02 \mathrm{~g}$ breed by the Lampung Center for Mariculture.

\section{Research Design}

A. ocellaris were distributed into 4 aquariums with a volume of $120 \mathrm{~L}$ each using a controlled recirculation system. The study was conducted using 4 density treatments: $0.17,0.37,0.67$, and 0.80 fish/L without replication. The acclimatizing process lasted 2 weeks at a temperature of $27-29{ }^{\circ} \mathrm{C}$ (Setiawati and Hutapea, 2011; Rushworth et al., 2011).

\section{Work Procedures}

Amphiprion ocellaris were kept for 61 days, sampling was conducted at the beginning, in the middle, and at the end of the maintenance period. The parameters measured during sampling were the fish's total length and weight. The effect of stocking density on growth was evaluated using the following equation (Chambel et al., 2015b):

$$
\begin{array}{ll}
\text { SGR }= & \frac{100 \times(\ln W \mathrm{t}-\ln W o)}{\mathrm{t}} \\
\text { Where } & \text { Specific Growth Rate (\%) } \\
\mathrm{SGR} & =\text { final fish weight }(\mathrm{g}) \\
\mathrm{Wt} & =\text { initial fish weight }(\mathrm{g}) \\
\mathrm{Wo} & =\text { inime (days) }
\end{array}
$$

Fish survival was observed daily until the end of the treatment. Calculation of the survival rate was done at the end of the treatment using the following equation:

$\mathrm{SR}=\frac{\mathrm{Nt}}{\mathrm{No}} \times 100 \%$

Where:

SR = Survival rate (\%)

$\mathrm{Nt} \quad=$ Final number of fish (individuals)

No = Initial number of fish (individuals)

The water quality was measured once a week with the following parameters: DO (dissolved oxygen) and temperature using a DO meter (Lutron DO $5510 \mathrm{HA}$ ), salinity using a refractometer (ABBE), and $\mathrm{pH}$ using a $\mathrm{pH}$ meter (Hanna). The feed was given ad satiation using the PF 1000 type feed. The feed was given twice daily in the morning and in the afternoon. Photoperiod was applied in this study at a 14:10 ratio (14 hours light, 10 hours dark) (Johnston et al., 2003).

\section{Data Analysis}

All the observation results were tabulated using the 2013 MS Office Excel program and were presented in the form of diagrams. The water quality data were analyzed descriptively and compared to the references.

\section{RESULTS AND DISCUSSION}

The results of the observation showed that the survival rate for 60 days presented in Table 1 had the highest result for K 2 at $98.18 \%$. The ocellaris clownfish in treatment $\mathrm{K} 4$ had the highest mortality 
rate at $21.67 \%$ and was suggested to be due to parasitic infection in the form of mold indicated by the white spots on the fish's body and tail.

Table 1. Survival rate and growth rate of the ocellaris clownfish during the experiment.

\begin{tabular}{lrrrr}
\hline Parameter & K 1 & K 2 & K3 & K4 \\
\hline Number (individuals) & 25 & 55 & 100 & 120 \\
Density (individuals per L) & 0.17 & 0.37 & 0.67 & 0.80 \\
Mortality & 1 & 1 & 2 & 26 \\
Nt & 24 & 54 & 98 & 94 \\
SR & $96.00 \%$ & $98.18 \%$ & $98.00 \%$ & $78.33 \%$ \\
\hline
\end{tabular}

Amphiprion ocellaris Cuvier, 1830 growth parameters during the rearing period can be seen in Figure 1. Differences in density affected the specific growth rate of $A$. ocellaris as seen in Figure 1 where the highest specific growth rate was found in
K1 which had the lowest stocking density at 0.17 individuals per $\mathrm{L}$ at $1.14 \%$ per day. This result corresponded with that of the study by Chambel et al. (2015b) where the stocking density with the highest growth was 0.5 individuals per L.

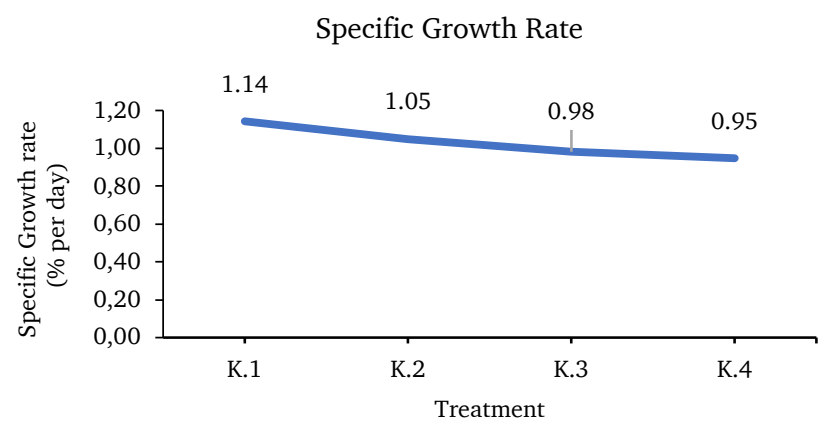

Figure 1. The Specific growth rate (SGR) of Amphiprion ocellaris during the rearing period.

The water quality parameters measured in this study are presented in Table 2. The results of the water quality measurements showed that the water quality of the rearing media for $A$. ocellaris was still within the optimum range for rearing. The similar values in the water quality measurements indicated that the recirculation system worked well. The $21.67 \%$ mortality rate in treatment $\mathrm{K} 4$ was indicated to be due to parasites adhering to the fish's body and fins instead of being caused by water quality.

Table 2. The water quality parameters during the experiment.

\begin{tabular}{llll}
\hline Parameter & Value & Reference & \\
\hline Temperature $\left({ }^{\circ} \mathrm{C}\right)$ & $27 \pm 0.3$ & $27.9-29.6$ & (Setiawati and Hutapea, 2011) \\
DO $(\mathrm{mg} / \mathrm{L})$ & $4.23 \pm 1.3$ & $5.0-5.5$ & (Ghosh et al., 2011) \\
$\mathrm{pH}$ & $7.2-8.4$ & $6.7-8.6$ & (Setiawati and Hutapea, 2011) \\
Salinity (g/L) & $28 \pm 1.3$ & 33 & (Chambel et al., 2015b) \\
Water debit & $0.42 \pm 0.2$ & $0.40 \pm 08$ & (Johnston et al., 2003) \\
(L/minute) & & & \\
\hline
\end{tabular}

\section{CONCLUSION}

The rearing of ocellaris clownfish $A$. ocellaris using a recirculation system resulted in a high survival rate (averaging above $90 \%$ ). The water quality parameters measured were still within the optimum 
range for ocellaris clownfish maintenance. The highest specific growth rate was found in treatment $\mathrm{K} 1$ at $1.14 \%$ per day. The best survival rate was in treatment $\mathrm{K} 2$ with a stocking density of 0.37 individuals per L. Therefore, it could be concluded that the optimum stocking density for the maintenance of the ocellaris clownfish $A$. ocellaris is 0.37 individuals per $\mathrm{L}$.

\section{ACKNOWLEDGEMENT}

This study was funded by the Pangandaran Marine and Fishery Polytechnique, the Marine and Fishery Research and Human Resources Center (Badan Riset dan Sumber Daya Manusia Kelautan dan Perikanan), Ministry of Marine Affairs and Fisheries, 2018/2019 Financial Year.

\section{REFERENCES}

Araujo, T., Miranda, F., Chambel, J., Mendes, S.L., Baptista, T. and Pedrosa, R., 2014. The effects of food and photoperiod on strobilation of Aurelia aurita polyps. Front. Mar. Sci. Conference Abstract: IMMR International Meeting on Marine Research 2014. doi: 10.3389/conf.fmars.2014.02.00129

Chambel, J., Pinho, R., Sousa, R., Ferreira, T., Baptista, T., Severiano, V., Mendes, S. and Pedrosa, R., 2015. The efficacy of MS-222 as anaesthetic agent in four freshwater aquarium fish species. Aquaculture Research, 46(7), pp.1582-1589. https://doi.org/10.1111/are.12308

Chambel, J., Severiano, V., Baptista, T., Mendes, S. and Pedrosa, R., 2015. Effect of stocking density and different diets on growth of Percula Clownfish, Amphiprion percula (Lacepede, 1802). Springerplus, 4(1), pp.1-7. https://doi.org/10. 1186/s40064-015-0967-x

Dambo, W.B. and Rana, K.J., 1993. Effect of stocking density on growth and survival of Oreochromis niloticus (L.) fry in the hatchery. Aquaculture Research, 24(1), pp.71-80. https://doi.org/10.1111/j. 13652109.1993.tb00829.x

de Oliveira, E.G., Pinheiro, A.B., de Oliveira, V.Q., da Silva Júnior, A.R.M., de Moraes, M.G., Rocha, Í.R.C.B., de Sousa, R.R. and Costa, F.H.F., 2012. Effects of stocking density on the performance of juvenile pirarucu (Arapaima gigas) in cages. Aquaculture, 370, pp.96101. https://doi.org/10.1016/j. aquaculture.2012.09.027

Dhaneesh, K.V., Devi, K.N., Kumar, T.A., Balasubramanian, T. and Tissera, K., 2012. Breeding, embryonic development and salinity tolerance of Skunk clownfish Amphiprion akallopisos. Journal of King Saud University-Science, 24(3), pp.201209. https://doi.org/10.1016/j. jksus.2011.03.005

Ghosh, S., Kumar, T.A., Vinoth, R., Balasubramanian, T., Dabbagh, A.R. and Keshavarz, M., 2011. Effect of short-term enrichment of wild zooplankton on survival of larval maroon Clownfish (premnas biaculeatus). Middle-East Journal of Scientific Research, 7(5), pp.674677. https://www.cabdirect.org/ cabdirect/abstract/20113243309

Gomes, L.C., Chagas, E.C., Martins J.H., Roubach, R., Ono, E.A. and Paula, L.J.N., 2006. Cage culture of tambaqui (Colossoma macropomum) in a central Amazon floodplain lake. Aquaculture, 253(1-4), pp.374-384. https://doi.org/10.1016/j.aquacult ure.2005.08.020

Johnston, G., Kaiser, H., Hecht, T. and Oellermann, L., 2003. Effect of ration size and feeding frequency on growth, size distribution and survival of juvenile clownfish, Amphiprion percula. Journal of Applied Ichthyology, 19(1), pp.4043. https://doi.org/10.1046/j. 1439-0426.2003.00351.x

Leatherland, J.F. and Cho, C.Y., 1985. Effect of rearing density on thyroid and interrenal gland activity and plasma and hepatic metabolite 
levels in rainbow trout, Salmo gairdneri Richardson. Journal of Fish Biology, 27(5), pp.583-592. https:// doi.org/10.1111/j.1095-8649.1985. tb03203.x

Moorhead, J.A. and Zeng, C., 2010. Development of captive breeding techniques for marine ornamental fish: a review. Reviews in Fisheries Science, 18(4), pp.315-343. https://doi.org/10.1080/10641262 .2010 .516035 .

Rushworth, K.J., Smith, S.D., Cowden, K.L. and Purcell, S.W., 2011. Optimal temperature for growth and condition of an endemic subtropical anemonefish. Aquaculture, 318(34), pp.479-482. https://doi.org/10. 1016/j.aquaculture.2011.06.004

Sari, O.V., Hendrarto, B. and Soedarsono, P., 2014. Pengaruh variasi jenis makanan terhadap ikan karang nemo (Amphiprion ocellaris Cuvier, 1830) ditinjau dari perubahan warna, pertumbuhan dan tingkat kelulushidupan. Journal of Management of Aquatic Resources, 3(3), pp.134-143. https:// ejournal3.undip.ac.id/index.php/m aquares/article/view/6665

Setiawati, K.M. and Hutapea, J.H., 2011. Pemeliharaan Benih Ikan Klon (Amphiprion ocellaris) Dengan Sistem Pengelolaan Air Yang Berbeda. Jurnal Riset Akuakultur, 6(2), pp.243-252. http://dx.doi. org/10.15578/jra.6.2.2011.243252.

Sharm, J.G. and Chakrabarti, R., 1998. Effects of different stocking densities on survival and growth of grass carp, Ctenopharyngodon idella, larvae using a recirculating culture system. Journal of applied Aquaculture, 8(3), pp.79-83. https://doi.org/10.1300/ J028v08n03_08 